\title{
Characteristics of infertile couples attending OPD of a teaching hospital
}

\author{
Parul Sinha $^{1}$, Kiran Pandey ${ }^{2}$, Anand Srivastava ${ }^{3}$, Iti Chowdhary ${ }^{1}$
}

\begin{abstract}
${ }^{1}$ Department of Obstetrics \& Gynaecology, Era's Lucknow Medical College, Lucknow, Uttar Pradesh, India ${ }^{2}$ Department of Obstetrics \& Gynaecology, UISEMH, GSVM Medical College, Kanpur, Uttar Pradesh, India ${ }^{3}$ Department of Pulmonary Medicine, KGMU, Lucknow, Uttar Pradesh, India
\end{abstract}

Received: 21 January 2015

Revised: 23 January 2015

Accepted: 16 February 2015

\author{
*Correspondence: \\ Dr. Parul Sinha, \\ E-mail: drparulanand@gmail.com
}

Copyright: (C) the author(s), publisher and licensee Medip Academy. This is an open-access article distributed under the terms of the Creative Commons Attribution Non-Commercial License, which permits unrestricted non-commercial use, distribution, and reproduction in any medium, provided the original work is properly cited.

\begin{abstract}
Background: Infertility is defined as failure to conceive even after one year of regular, frequent and unprotected intercourse. Infertility has, in the last few years surfaced in society as a significant problem affecting as many as $15 \%$ of couples. This study aimed at identifying the characteristics of infertility among Indian couples.

Methods: The present study was carried out on 100 infertile couples attending the OPD of upper India sugar exchange maternity hospital attached to GSVM medical college, Kanpur, other hospital and nursing homes of Kanpur. Both the partners were completely evaluated by taking proper history, examination and investigation to assess the cause of infertility.

Results: Majority of female partners were between ages of 25-29. Female factors were found in $45 \%$ couples and male factors in $30 \%$ couples. Among female factors, tuboperitoneal factor was found in $32 \%$ cases and ovulatory factor was found in $40 \%$ cases. Oligospermia was the commonest cause in male factor infertility.

Conclusions: From this study we concluded that infertility is a public health problem in India and the main infertility pattern is a primary rather than secondary infertility.
\end{abstract}

Keywords: Infertility, Male factors, Female factors, Semen analysis, Ovulatory factors, Tubal patency tests, Socioeconomic factors

\section{INTRODUCTION}

Infertility is defined as failure to conceive even after one year of regular, frequent and unprotected intercourse. ${ }^{1}$ Infertility has, in the last few years surfaced in society as a significant problem affecting as many as $15 \%$ of couples. A study by Templeton et al. (1990) found a prevalence of infertility within general population of $14 \% .^{2}$ It is not merely a somatic illness but a human problem implicating social and psychological aspects that require search for solutions unlikely to be relegated to a sole medical option. The couples are being faced with the problem of infertility since time immemorial, but the face of medicine is changing fast and every new day brings forth new researches and development in managing infertility and this inculcates fresh hopes among infertile couples.

Infertility is of two types: Primary infertility - when no previous pregnancies have occurred. Secondary infertility - when patient has achieved one previous pregnancy (not necessarily a live birth). Infertility can be attributed to male causes in approximately $25-40 \%$, female causes to $40-55 \%$, both in 10-20\% and unexplained causes in 10$15 \%$ cases. Unexplained infertility refers to infertility with normal results on standard investigations (normal semen analysis, a normal uterine cavity and bilateral tubal patency). 


\section{METHODS}

The present study was carried out on 100 infertile couples attending the OPD of upper India sugar exchange maternity hospital attached to GSVM medical college, Kanpur, other hospital and nursing homes of Kanpur. Both the partners were completely evaluated by taking proper history, examination and investigation to assess the cause of infertility. The study couples had at least one year infertility and had undergone a basic infertility evaluation consisting of detailed anamnesis (age, duration of infertility, type of infertility, medical history, previous surgical interventions, lifestyles, body mass index), hormone concentrations at the third day of menstrual cycle (FSH, LH, estradiol-17, TSH and PRL) and semen analysis. Physical and gynaecological examinations were performed on all the women subjects. Tubal patency was confirmed by hysterosalpingography or laparoscopy. Endometrial biopsy was done in premenstrual phase showing normal secretory phase or abnormal proliferative phase to detect ovulation and any endometrial pathology. Hysteroscopy and hysterosalpingography were done in proliferative phase to detect any endometrial and tubal pathology and patency of tubes. Laparoscopy was done to rule out any uterine, tubal and endometrial pathology. Presence of follicles and old marks of ovulation are noted. Laparochromopertubation was done to directly visualize the tubal patency. Baseline transabdominal ultrasonography was done to detect any pathology of female genital tract and to assess ovulation and endometrial thickness. Patients with stage 3-4 endometriosis, intracavitary lesion in uterus, previous surgery on ovaries were excluded from the study.

Complete semen analysis was done by manual method (in haemocytometer - Neubauer chamber or Markler chamber) or autoanalyser in laboratory. Specimen was collected after 3-5 days of abstinence in a clean sterilized jar. Standard values of semen analysis as laid by WHO were taken.

\section{RESULTS}

In this study most of the patients $73 \%$ were of primary infertility and only $27 \%$ cases were of secondary infertility.

Table 1: Patient's distribution according to the type of infertility.

\begin{tabular}{|lll|}
\hline $\begin{array}{l}\text { Type of } \\
\text { infertility }\end{array}$ & $\begin{array}{l}\text { No. of } \\
\text { cases }\end{array}$ & $\begin{array}{l}\text { Percentage } \\
(\%)\end{array}$ \\
\hline Primary & 73 & 73 \\
\hline Secondary & 27 & 27 \\
\hline Total & 100 & 100 \\
\hline
\end{tabular}

Out of 100 couples most of the female partners $42 \%$ were between 25-29 years. Only 2\% were aged 40 years and more. Mean age of female partners of the study group was 28.10 years.
Table 2: Age distribution of female partners.

\begin{tabular}{|lllll|}
$\begin{array}{l}\text { Age } \\
\text { group }\end{array}$ & $\begin{array}{l}\text { Primary } \\
\text { infertility }\end{array}$ & $\begin{array}{l}\text { Secondary } \\
\text { infertility }\end{array}$ & Total & $\begin{array}{l}\text { Percentage } \\
(\%)\end{array}$ \\
\hline $15-19$ & 02 & 01 & 03 & 03 \\
\hline $20-24$ & 21 & 03 & 24 & 24 \\
\hline $25-29$ & 37 & 05 & 42 & 42 \\
\hline $30-34$ & 10 & 12 & 22 & 22 \\
\hline $35-39$ & 03 & 04 & 07 & 07 \\
\hline$>40$ & 00 & 02 & 02 & 02 \\
\hline Total & 73 & 27 & 100 & 100 \\
\hline
\end{tabular}

In this study most of the couples $88 \%$ presented with the duration of less than 9 years. Out of 100 couples, maximum of $56 \%$ has duration of infertility between 3-6 years. $4 \%$ couple had infertility of more than 12 years duration. The mean duration of infertility was 5.58 years.

Table 3: Patient's distribution according to the duration of infertility.

\begin{tabular}{|lll|}
$\begin{array}{l}\text { Duration } \\
\text { (years) }\end{array}$ & $\begin{array}{l}\text { No. of } \\
\text { cases }\end{array}$ & $\begin{array}{l}\text { Percentage } \\
(\%)\end{array}$ \\
\hline $1-3$ & 13 & 13 \\
\hline $3-6$ & 56 & 56 \\
\hline $6-9$ & 10 & 19 \\
\hline $9-12$ & 8 & 8 \\
\hline$>12$ & 4 & 4 \\
\hline Total & 100 & 100 \\
\hline
\end{tabular}

In this study out of 100 couples, the female causes were present in $45 \%$ cases, male causes were present in $30 \%$ cases, combined factors were found responsible in $12 \%$ cases and in $13 \%$ patients cause of infertility was unexplained.

Table 4: Distribution of cases according to the cause of infertility.

\begin{tabular}{|lll|}
\hline $\begin{array}{l}\text { Cause of } \\
\text { infertility }\end{array}$ & $\begin{array}{l}\text { No. of } \\
\text { cases }\end{array}$ & $\begin{array}{l}\text { Percentage } \\
(\%)\end{array}$ \\
\hline Female & 45 & 45 \\
\hline Male & 30 & 30 \\
\hline Both & 12 & 12 \\
\hline Unexplained & 13 & 13 \\
\hline Total & 100 & 100 \\
\hline
\end{tabular}

In this study out of 100 infertility couples 45 (45\%) females were having some causative factor and in 12 $(12 \%)$ both partners contributed to infertility.

Thus total of $57(57 \%)$ females were having some causative factors out of which $23(40.35 \%)$ had ovulatory factor, $18(31.57 \%)$ had tuboperitonial factor, $3(5.26 \%)$ had uterine factor, $5(8.77 \%)$ had cervical factor and 8 $(14.03 \%)$ had some other causes of infertility. 
Table 5: Patient's distribution according to the cause of female infertility.

\begin{tabular}{|lll|}
\hline Factors causing infertility & $\begin{array}{l}\text { No. of } \\
\text { cases }\end{array}$ & $\begin{array}{l}\text { Percentage } \\
(\%)\end{array}$ \\
\hline Ovulatory factor & 23 & 40.35 \\
\hline Tubo peritoneal factor & 18 & 31.57 \\
\hline Uterine factor & 03 & 5.26 \\
\hline Cervical factor & 05 & 8.77 \\
\hline Other causes & 08 & 14.03 \\
\hline Total & $45+12$ & 100 \\
\hline
\end{tabular}

Among the male causes of infertility, oligospermia was present in $12(40 \%)$ cases. Azoospermia in 5 (16.39\%) cases, asthenospermia $4(13.33 \%)$, teratospermia 2 $(6.66 \%)$, retrograde ejaculation in $1(3.33 \%)$, impotence 2 $(6.66 \%)$ and combined factors were present in $4(13.33 \%)$ cases.

Table 6: Distribution of cases according to male causes.

\begin{tabular}{|lll|}
\hline Causes & $\begin{array}{l}\text { No. of } \\
\text { patients }\end{array}$ & $\begin{array}{l}\text { Percentage } \\
(\%)\end{array}$ \\
\hline Oligospermia & 12 & 40 \\
\hline Azoospermia & 05 & 16.33 \\
\hline Asthenospermia & 04 & 13.33 \\
\hline Teratospermia & 02 & 6.66 \\
\hline Retrograde ejaculation & 01 & 3.33 \\
\hline Impotence & 02 & 6.66 \\
\hline Combined & 04 & 13.33 \\
\hline
\end{tabular}

Out of 100 cases of endometrial biopsy, 69 (69\%) cases were having normal secretory endometrium, 23 (23\%) cases showed proliferative or corpus luteum deficient endometrium and in $5(5 \%)$ cases acute endometritis were present.

Table 7: Patient's distribution according to results of endometrial biopsy.

\begin{tabular}{|lll|}
\hline Biopsy & Cases & $\begin{array}{l}\text { Percentage } \\
(\%)\end{array}$ \\
\hline Normal secretory endometrium & 69 & 69 \\
\hline Proliferative endometrium & 23 & 23 \\
\hline Tissue deficient & 03 & 03 \\
\hline Acute endometritis & 05 & 05 \\
\hline Total & 200 & 100 \\
\hline
\end{tabular}

Out of 100 patients, hysterosalpingography was done in 90 patients. Of the remaining 10 patients, 6 had tubercular endometritis and 4 had cervical and vaginal infections. In 20 doubtful cases chromopertubation and laparodiagnosis was done. So according to tubal patency, test results $77(77 \%)$ patients had both tubes patent 10 (10\%) patients had both tubes blocked and 5 (5\%) had one tube blocked.
Table 8: Patients distribution according to results of tubal patency test.

\begin{tabular}{|lll|}
\hline $\begin{array}{l}\text { Results of tubal } \\
\text { patency test }\end{array}$ & $\begin{array}{l}\text { No. of } \\
\text { cases }\end{array}$ & $\begin{array}{l}\text { Percentage } \\
(\%)\end{array}$ \\
\hline Patent & 77 & 77 \\
\hline Bilateral blocked & 08 & 08 \\
\hline Unilateral blocked & 05 & 05 \\
\hline Test not done & 10 & 10 \\
\hline Total & 100 & 100 \\
\hline
\end{tabular}

\section{DISCUSSION}

Infertility is a multifactorial problem affecting $2-10 \%$ couples and has far reaching social and psychological implications.100 patients attending the OPD of UISEMH were taken as a study group. Couples were thoroughly evaluated and investigated to know the cause of infertility. This study showed that majority of the patients $146(73 \%)$ had primary infertility and $54(27 \%)$ had secondary infertility (Table 1). Our findings were comparable to the results of Templeton et al and Keer (1990) (primary infertility in $75 \%$ and secondary infertility in $25 \%$ cases). ${ }^{2}$ In this study it was found that out of 100 couples, $42(42 \%)$ female partners were between 25-29 age group. Only $2 \%$ were 40 years or more. The mean age of infertile females of study group was 28.10 year \pm 5.06 years (Table 2). Most of the couples i.e. $88 \%$ presented with duration of less than 9 years. In this study $56(56 \%)$ couples presented with infertility of 3-6 years duration.4\% couples had infertility of more than 12 years duration. Mean duration of infertility was 5.58 years (Table 3 ). This study showed that female factors were responsible in 45 (45\%) cases, male factors in $30(30 \%)$, combined factors in $12(12 \%)$ and the cause remained unexplained in $13(13 \%)$ cases (Table 4). James M. Wheeler reported after a clinical study that female factors are solely implicated in $30 \%$ cases, male factors are involved in $30 \%$ cases and $10 \%$ cases are of unexplained infertility. ${ }^{3}$ In this study out of 100 infertile couples 45 females were having some causative factor and in 12 both partners contributed to infertility. Thus total of $57 \%$ females were having some causative factors out of which ovulatory factors were responsible in $23(40.35 \%)$ cases, tuboperitoneal factor in $18(31.57 \%)$ cases, uterine factor in $3(5.26 \%)$ cases cervical factor in $5(8.77 \%)$ cases and other causes were responsible in $8(14.03 \%)$ cases (Table 5). Rouland et al. (1980) reported anovulation in 24\%; male factor $13 \%$, tubal factors $34 \%$ and unexplained $29 \%$ as cause of infertility. ${ }^{4,5}$

Ovulatory dysfunction accounts for approximately 30$40 \%$ of all cases of female infertility. Studies have suggested that corpus luteal insufficiency and luteinized unruptured follicle produce an abnormal luteal phase which in turn is an important luteal factor responsible for infertility. Insufficient progesterone secretion leads to poor secretory activity of endometrium and improper bed for implantation. ${ }^{6-8}$ The diseases of ovary, which most 
frequently cause infertility, are polycystic ovarian disease (chronic anovulation syndrome), ovarian endometriosis, luteinized unruptured follicle, empty follicle syndrome. Among chronic anovulation syndromes - hyper and hypogonadism cause ovarian amenorrhoea where ovaries are similar to women with menopause (small size, very few or absent follicles). The polycystic ovarian syndrome is characterised by an abnormal pulsatile GnRH release, which causes LH hypersecretion and FSH hyposecretion. Latter is not able to stimulate the growth and maturation of follicles. There is hyperandrogenism with hirsutism and obesity and is responsible for hypertrophy and stromal hyperechogenecity. In PCOS ovarian volume is $>10 \mathrm{~cm}^{3}$ presence of numerous $\geq 5$ peripheral microfollices with hyperechoic stroma.

Tuboperitoneal factors account for $30-40 \%$ cases of female infertility. The incidence of tubal infertility occurs in $12 \%, 23 \%, 54 \%$ cases after $1^{\text {st }}, 2^{\text {nd }}$ and $3^{\text {rd }}$ episodes of PID respectively. ${ }^{9}$

Uterine factors are associated with recurrent pregnancy loss rather than infertility. Buttram VC Reiter RC (1981) stated that fibroids are infrequent cause of infertility ${ }^{10}$ and Berkeley AS et al reported that abdominal myomectomy may even cause infertility through the formation of postoperative adhesions. ${ }^{11}$

Mohammed et al. (1985) stated that infertility is said to be idiopathic or unexplained when a couple fails to conceive and no definite cause for infertility can be diagnosed after a complete work-up. ${ }^{12}$ Collins and Rowe (1988) suggested that such patients have potential for spontaneous conception inversely proportional to the number of years of infertility and the age of female partner. ${ }^{13}$

This study shows that out of 100 couples with infertility, $30(30 \%)$ cases were responsible solely for male factor infertility with oligospermia in 12 (40\%) cases, azoospermia in $5(16.39 \%)$ cases, low motility in 4 $(13.33 \%)$ cases, teratozoospermia in $2(6.66 \%)$ cases, retrograde ejaculation in $1(3.33 \%)$ cases, impotency in 2 $(6.66 \%)$ and combined factor in $4(13.33 \%)$ each (Table 6). WHO group in 1994 studied the causes and incidence rates in male infertility patients and stated that varicocele was found in $37.4 \%$ cases, idiopathic infertility in $25.4 \%$ cases, testicular failure in $9.4 \%$ cases, obstruction of vas or ejaculatory duct in $6.1 \%$ cases, cryptorchidism in $6.1 \%$ cases, and low semen volume in $4.7 \%$ cases. Semen agglutination in $1.9 \%$ cases, semen viscosity in $1.9 \%$ and other causes in $5.9 \%$ cases.

Results of endometrial biopsy showed that out of 100 cases $69 \%$ were having normal secretory endometrium, $23 \%$ showed proliferative or corpus luteum deficient endometrium and in $5 \%$ cases acute endometritis was present (Table 7). Wentz AC (1986) suggested that findings of secretory endometrium in endometrial biopsy done 2-3 days before onset of menstruation confirms ovulation and its major role is in diagnosis of luteal phase defects. Biopsy is interpreted by dating of endometrium according to criteria of Noyes Hertiz and Rock. ${ }^{14}$

Tuboperitoneal factor was one of the major causative factor as reported by Rowland ${ }^{4}$ et al. (1980), Pepperall ${ }^{5}$ (1983) and Templeton ${ }^{2}$ (1995), so tubal patency tests were done in the patients (Table 8). Out of 100 patients, hysterosalpingography was done in 90 patients. Of the remaining 10 patients, 6 had tubercular endometritis and 4 had cervical and vaginal infection. In 20 doubtful cases chromopertubation and laparodiagnosis was done. $77 \%$ patients had both tubes patent, $10 \%$ had both tubes blocked and $5 \%$ had one tube blocked.

\section{CONCLUSIONS}

From this study we concluded that infertility is a public health problem in India and the main infertility pattern is a primary rather than secondary infertility. Majority of female partners were between ages of 25-29. Female factors were found in $45 \%$ couples and male factors in $30 \%$ couples. Among female factors, tuboperitoneal factor was found in $32 \%$ cases and ovulatory factor was found in $40 \%$ cases. Oligospermia was the commonest cause in male factor infertility.

\section{Funding: No funding sources \\ Conflict of interest: None declared \\ Ethical approval: Not required}

\section{REFERENCES}

1. Hammond SH. Evaluation of infertile couple. Obstet Gynecol Clin North Am. 1986;14(4):821-30.

2. Templeton AA, Penny GC. The incidence characteristic and prognosis of patients whose infertility is unexplained. Fertil Steril. 1982;37:17582.

3. James M, Wheeler, Marry Lake Polan. Etiology of infertility female factors. In: James M, Wheeler, Marry Lake Polan, eds. De.Cherneys a Textbook of Infertility. 8th ed. New York, NY: New Hope Fertility Ctr; 2012.

4. Rowland M. Infertility therapy-effect of innovations and increasing experience $\mathbf{J}$ Reprod Med. 1980;25:42-6.

5. Pepperell RJ. Rational approach to ovulation induction. Fertil Steril. 1983;40:1-14.

6. Cox LW. Infertility a comprehensive programme. BJOG. 1975;82(1):2-6.

7. Kaufman FR, Kogut MD, Donnell GN, Goebelsmann U, March C, Koch R. Hypergonadotropic hypogonadism in females with galactocemia. N Engl J Med. 1981;304:994-8.

8. Summaria V, Speca S, Mirk P. Ovarian factor infertility. Ray (Italy). 1998 Oct-Dec;23(4):709-26.

9. Westron L. Incidence, prevalence and trends of acute PID and its consequence in industrialized countries. Am J Obstet Gynecol. 1980;138:880-92. 
10. Buttram VC, Reiter RC. Uterine leiomyoma; etiology, symptomatology and management. Fertil Steril. 1981;36:433-45.

11. Berkeley AS, Decherney AH, Plan ML. Abdominal myomectomy and subsequent fertility. Obstet Gynecol. 1983;156:319-22.

12. Mohmad A, Aboulghar, Rajan T, Mansoor, Gamali, Saron. Ovarian super stimulation and IUI for treatment of unexplained infertility. Fertil Steril. $1985 ; 16: 3$.
13. Collins JA. Diagnosis assessment of the infertile female partner. Cirr Probi Obstet Gynecol Fertil. 1988;11:36-42.

14. Wentz AC, Herbert CM III, Mexon WS, Hill GAP, Pittaway DE. Cycle of conception endometrial biopsy. Fertil Steril. 1986;46:1996-9.

DOI: $10.5455 / 2320-1770 . i j r \operatorname{cog} 20150417$

Cite this article as: Sinha P, Pandey K, Srivastava A, Chowdhary I. Characteristics of infertile couples attending OPD of a teaching hospital. Int J Reprod Contracept Obstet Gynecol 2015;4:373-7. 